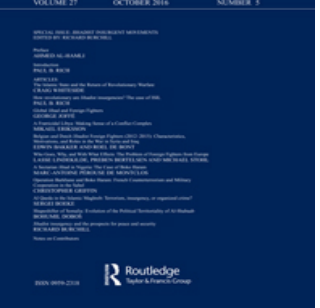

\title{
Al Qaeda in the Islamic Maghreb: Terrorism, insurgency, or organized crime?
}

\section{Sergei Boeke}

To cite this article: Sergei Boeke (2016) Al Qaeda in the Islamic Maghreb: Terrorism, insurgency, or organized crime?, Small Wars \& Insurgencies, 27:5, 914-936, DOI: 10.1080/09592318.2016.1208280

To link to this article: https://doi.org/10.1080/09592318.2016.1208280
(2) 2016 The Author(s). Published by Informa UK Limited, trading as Taylor \& Francis Group
Published online: 05 Aug 2016.

Submit your article to this journal $\pi$

Џ Article views: 11076

View Crossmark data $\asymp$

Citing articles: 5 View citing articles ¿ 


\title{
Al Qaeda in the Islamic Maghreb: Terrorism, insurgency, or organized crime?
}

\author{
Sergei Boeke
}

Institute of Security and Global Affairs, Leiden University, the Netherlands

\begin{abstract}
After incurring significant losses during France's 2013 Operation Serval in Mali, Al Qaeda in the Islamic Maghreb (AQIM) is back. Mokhtar Belmokhtar has rejoined the group, violent attacks are on the increase, and southern Libya offers elements of the group a new safe-haven. This article takes a long view on AQIM, looking at its objectives and ideology, organizational structure, relationship with the local population and revenue model to determine whether they should be labelled as terrorists, insurgents, or ordinary criminals. The article concludes that AQIM generally follows a strategy of terrorism, while some elements and modus operandi could also be indicative of a strategy of insurgency. AQIM's primary commanders have a long-standing relationship with the global Al Qaeda movement, are unlikely to be seduced by the Islamic State, and enjoy significant autonomy in conducting their operations. There is, however, little evidence that supports the view that AQIM is a criminal organization behind a religious façade, and its Salafi-jihadist ideology remains a leading determinant.
\end{abstract}

ARTICLE HISTORY Received 16 February 2016; Accepted 8 March 2016

KEYWORDS AQIM; terrorism; insurgency; Mali; Sahel; intervention

\section{Introduction}

On 20 November 2015, two gunmen attacked the luxury Radisson Blu hotel in Bamako, Mali, killing 22 people before they were themselves shot by French and Malian Special Forces. The attack was initially claimed by Al Murabitoon, led by Mokhtar Belmokhtar (Khalid Abu Al Abbas), a union of two offshoots from Al Qaeda in the Islamic Maghreb (AQIM). Two weeks later, the'emir' or commander of AQIM, Abdelmalek Droukdel (Abu Musab Abdel Wadoud) announced that Al Murabitoon had joined AQIM and that the hotel attack was their first joint operation. ${ }^{~ T h e n ~ o n ~} 15$ January 2016, the Splendid hotel and Cappuccino Café in Ouagadougou, Burkina Faso, were hit by a similar attack, killing 30 civilians and wounding more than 56 . On the same day, militants attacked a police convoy 
and kidnapped an elderly Australian couple in the north of the country. AQIM claimed responsibility for the hotel attack and the kidnapping. ${ }^{2}$ While these spectacular attacks garnered much international media attention, throughout 2015 neighbouring Mali had already faced a resurgent AQIM. Suicide bombings, rocket attacks, and ambushes inflicted many casualties on local security forces and made the UN Multidimensional Integrated Stabilization Mission in Mali (MINUMSA) one of the most dangerous UN missions ever, with some 60 peacekeepers killed already.

AQIM is not the only armed group responsible for the violence in northern Mali. There is a plethora of armed factions including criminal enterprises, Tuareg separatists, government aligned militias, and several groups that espouse a Salafi-jihadist agenda. In 2012, an armed uprising was started by the'Mouvement national de libération de l'Azawad' (MNLA), a Tuareg separatist faction, aided by three jihadist groups: AQIM, its offshoot 'Mouvement pour l'unicité et le Jihad en Afrique de l'Ouest' (MUJAO), and Ansar Dine. Once this coalition had forcefully evicted the Malian army and government administration from the north, what started as a secular rebellion was hijacked by the three Salafi-jihadist groups. They would govern the north until January 2013, when their sudden attack on the south provoked a French military intervention. Upon request of the beleaguered government in Bamako, France launched Operation Serval and liberated the north from the jihadists. ${ }^{3}$ Since July 2013 the UN has deployed MINUSMA, France has launched a new, regional counterterrorist mission called Operation Barkhane, and the Algiers peace process is attempting to reconcile Tuareg separatists with factions that are aligned with the Malian government and the government itself. While Operation Serval inflicted serious losses on the jihadist groups in 2013, and incidental raids conducted by Barkhane have killed highlevel terrorist commanders since, the groups are again becoming more active. ${ }^{4}$

This article will focus on AQIM as the main organization responsible for terrorist attacks in the Sahel and as the 'mother' of several violent offshoots. These include MUJAO and Belmokhtar's Al Murabitoon, which rejoined after a split lasting nearly two years. Ansar Dine and its leader, lyad ag Ghali (Shayk Abu Fadl), are closely allied to AQIM and are in turn well connected to the newly formed Macina Liberation Front. ${ }^{5}$ The exact relationship between the major jihadist groups remains difficult to discern, and the example of an important Malian jihadist, Oumar Ould Hamaha, illustrates how a commander can switch from AQIM to Ansar Dine and finally to MUJAO. ${ }^{6}$ It is no coincidence that Belmokhtar has recently rejoined forces with AQIM: both are fiercely loyal to AI Qaeda's leader Ayman Al-Zawahiri and they are facing increasing competition from the Islamic State (IS). In the north, IS has established a firm foothold in Libya, and in the south, in Nigeria, Boko Haram has already pledged its allegiance to Al-Baghdadi. A spokesman for MUJAO announced the group's allegiance to IS in May 2015, but this was quickly denied by other group members. ${ }^{7}$ The increase of violence in Mali and beyond, an uptake of media announcements by AQIM 
commanders, and the budding competition with IS merits a new analysis of AQIM. Taking a long view of AQIM's origins and actions, this article uses a conceptual framework to analyse whether the organization should be categorized as an insurgency, terrorist group, or crime syndicate.

\section{Labels, definitions, and concepts}

AQIM has been the focus of significant academic scholarship, although many authors have confined their research to one article, frequently preferring a descriptive analytical approach to a conceptual or theoretical one. Mathieu Guidère has published extensively on AQIM and was one of three experts consulted by the Associated Press to determine the authenticity of several Al Qaeda letters that were discovered in Timbuktu, Mali. ${ }^{8}$ Jean-Pierre Filiu, who is an Arabist like Guidère, has equally written quality works on AQIM, rich in primacy sources, before broadening his scope to Al Qaeda in general and the Islamic State. ${ }^{9}$ Many authors have researched AQIM's Algerian roots, its relationship with Al Qaeda, and the dichotomy between its focus on the 'near' or 'far enemy', with Jean-Luc Marret notably labelling AQIM a 'glocal' organization. ${ }^{10}$ Andrew Lebovich has recently published several works on AQIM and other related Sahel jihadist groups. ${ }^{11}$ Nonetheless, the existing body of literature on AQIM is - understandably - strongly embedded in the field of terrorism studies, with consequently neither an argued case for its terrorist label, nor a consideration of other classifications and their potential implications.

From a policy perspective, the decision to label an armed group as terrorists, insurgents, or criminals is an important one. Terrorism is a politically loaded term and is dependent on the subjective opinion of the observer, illustrated by the adage that one man's terrorist is another's freedom fighter. Framing a group as terrorists effectively delegitimizes them, while simultaneously justifying a policy of violence in response. As Philip Herbst argues, '[c]onveying criminality, illegitimacy, and even madness, the application of the term terrorist shuts the door to discussion about the stigmatized group or with them, while reinforcing the righteousness of the labellers, justifying their agenda's and mobilising their responses.12 Conversely, labelling a group as ordinary criminals (notwithstanding that terrorism is also illegal), belittles the underlying grievances, ideologies, and motivations, attributing their actions to solely personal, often material gain. In all cases, the designated label channels a policy reaction that is anchored in the very different fields of counterterrorism, counterinsurgency (COIN), or law enforcement, each centred around its own principles, dogmas, and common practices.

AQIM has been designated a terrorist group by the United Nations Security Council, the United States, and the European Union. Nonetheless, reaching consensus on the definition of terrorism has proven to be extremely difficult; neither academia nor the UN can agree on such a value-laden and subjective term. 
Avoiding the debate on definitions, this article will use the revised academic definition of terrorism as formulated by Alex Schmid:

Terrorism refers on the one hand to a doctrine about the presumed effectiveness of a special form or tactic of fear-generating, coercive political violence and, on the other hand, to a conspiratorial practice of calculated, demonstrative, direct violent action without legal or moral restraints, targeting mainly civilians and non-combatants, performed for its propagandistic and psychological effects on various audiences and conflict parties. ${ }^{13}$

The concept insurgency has provoked less debate, with general recognition that it is a strategy (not a tactic) to achieve political and military control over a population and territory. Traditionally insurgencies have consisted of irregular movements that have sought to mobilize a part of the population to assist in overthrowing the governing authorities. ${ }^{14}$ Nonetheless, distinguishing between terrorists and insurgents remains fraught with difficulty, as they often share the same modus operandi.

According to Duyvesteyn and Fumerton, it is essential to regard terrorism and insurgency as two distinct strategies of irregular war. ${ }^{15}$ The fundamental differences can be divided into three categories. First, the political objectives differ. Terrorism aims to provoke a response through violence to attain a political effect. Insurgents, conversely, intend to force political change through political and military control of a territory and its population. Secondly, the organizational structures differ as a result of the diverging objectives. Terrorists generally act in small and secret conspiracies, while insurgencies need a large and relatively open shadow state structure. Finally, for organizations following a terrorist strategy, active involvement of the population is not critical for success, although public support can shape and constrain both the actions of terrorists and the governments that counter them. ${ }^{16}$ Conversely, for an insurgency, control of or support from the population is essential for strategic success.

This article will use Duyvesteyn and Fumerton's three categories to examine AQIM and add a fourth element: the financial revenue model. By their very nature, illegal organizations like terrorist or insurgent groups will revert to illegal activities to fund their operations. It is important to investigate whether these fundraising activities present an intrinsic clash with the group's professed ideology. For example, drugs are officially haram (forbidden or sinful) in Islam, and even smoking and alcohol were banned when the jihadists governed northern Mali. If they subsequently traffic these goods, it could imply that material gain trumps religious or ideological motives, moving the classification of the organization into the domain of organized crime. When the gap between preaching and practice is sufficiently large, this can be exploited to undermine the group's legitimacy and credibility.

This distinction between terrorism and insurgency, and even the relevance and usefulness of the exercise, is not without controversy. James Khalil, noting that academic research is stove-piped into these two categories with parallel 
literatures sharing few insights and sources, argues that it is impossible to arbitrarily impose binary distinctions upon continuous variables such as population support and control of territory. ${ }^{17}$ David Kilcullen and John Mackinlay have argued that Al Qaeda should be seen as a global insurgency that uses terrorist tactics, since the global jihad has the objective of reinstating the Caliphate and replacing apostate local regimes. ${ }^{18}$ Conceptual confusion is compounded by the complexities of the Sahel. In Mali alone, there are a more than a dozen armed groups, including separatists, militias, and jihadi groups. They have different objectives and oscillate between competition and cooperation, with fighters frequently switching groups. 'Last year alone', a Tuareg explained to Peter Tinti in 2014, 'there are people who have changed from Malian military, to separatist rebel, to jihadist, to French ally, all while being narco-traffickers.' ${ }^{19}$

\section{AQIM's historical roots}

The origins of AQIM lie in the crucible of the Algerian civil war. Its current generation of commanders, including the Emir Droukdel and commanders such as Belmokhtar and Djamel Okacha all hark back to the original insurgency against the Algerian government. In 1992 a broad Islamist movement was robbed of an impending electoral victory by a military coup that cancelled the elections. Algeria immediately descended into violence that only abated at the end of the decade, costing an estimated 200,000 lives. 'Afghan Algerians', the so-called foreign fighters who had returned from 'jihad' or training camps in Afghanistan, played a central role in the conflict. These trained combatants, many of whom had developed personal bonds with the future Al Qaeda leadership and had been infused with its ideology, formed the nucleus of the 'Groupe Islamique Armé' (GIA). The GIA was initially only one of many groups fighting the government, but by 1994 had become the predominant and most violent faction. Based on Salafi-jihadist ideology, it had a particularly uncompromising stance, symbolized by its motto: no agreement, no truce, no dialogue. ${ }^{20}$ Those that the group labelled takfir (enemies of Islam), were classified as legitimate targets and therefore deserved to be killed, even if they were Muslim elderly, women, or children. Several notorious fatwas by the preacher Abu Qatada in the Salafist weekly bulletin Al Ansar (the 'Partisan'), printed in London, justified GIA massacres. ${ }^{21}$

The GIA specifically targeted foreigners; first in Algeria and later in France. In December 1994 the GIA hijacked Air France 8969 from Algiers to Paris. France was the former colonial oppressor, and it was hated for its support of the military regime in Algiers. The hijackers probably intended to fly the plane into the Eiffel Tower but were diverted to Marseille to refuel, where the plane was stormed by elite French police. In 1995 eight bombs exploded in the Paris underground, and a year later, seven Tibherine monks were abducted and beheaded in Algeria, horrifying the French public. These actions contributed to continued international support for the military regime in its fight against the Islamists, and a 
soft stance on the mass torture and extrajudicial executions that had become institutionalized as part of its counterterrorism policy. ${ }^{22}$ There is a strong body of evidence, including testimonies from military defectors, indicating that the security service, the Département du Renseignement et de la Securité (DRS), infiltrated and manipulated the GIA. Agents provocateurs fostered infighting and purges, and its wanton violence undermined the credibility of the general Islamic opposition among locals and the international community. Even investigations into the Air France hijacking and Tibherine murders point to a duplicitous role of the DRS. ${ }^{23}$

The turning point occurred in early 1998, when hundreds of civilians were massacred in the villages of Rais, Benthalla, and others. Here, too, were worrying signs of military units aiding and abetting mass murder. ${ }^{24}$ The magazine Al Ansar distanced itself from the GIA, and a large faction split off, founding the 'Groupe Salafiste pour la Prédication et le Combat' (GSPC), vowing only to hit government targets. The last remnants of the GIA used the government's reconciliation programme to defect or were hunted down by the Algerian military. Bin Laden and the newly formed AI Qaeda supported the creation of the GSPC and its Afghan Algerians. ${ }^{25}$ While the new group firmly aligned itself with the Salafi-jihadist AI Qaeda ideology, in its first communiqué in September 1998 the group emphasized its objective of toppling the Algerian regime, but in no way mentioned any foreign enemy. ${ }^{26}$ On 11 September 2003, the GSPC's emir pledged allegiance to Bin Laden and Mullah Omar in a communiqué. ${ }^{27}$ On 11 September 2006, exactly five years after 9/11, Al Qaeda leader Al-Zawahiri announced that the GSPC had joined Al Qaeda and urged them to become 'a bone in the throat of the American and French crusaders.'28 On 26 January 2007 the GSPC, led by Droukdel, announced that it had rebranded itself 'AI Qaeda in the land of the Islamic Maghreb'.

In the mid-2000s, many GSPC/AQIM fighters travelled to Iraq to join the fight against the 'American occupier'. Al-Zarqawi, the leader of Al Qaeda in Iraq (AQI), and Droukdel formed a close relationship, releasing propaganda statements in each other's support. ${ }^{29}$ AQIM adopted several modus operandi of AI Qaeda in Iraq, such as suicide bombings which had hardly been used by the GIA during the Algerian civil war. The ability to hit hardened targets such as UN facilities and well-protected military installations has since been an enduring AQIM capability. Although AQIM was inspired by Al-Zarqawi and copied some of his tactics, Abu Yahya al-Libi, a high-ranking AI Qaeda official, used the example of the GIA to warn Al-Zarqawi that his brutality and wanton cruelty would alienate the local population and lead to his demise. ${ }^{30} \mathrm{Al}$-Zarqawi ignored the warning, lost popular support, and was killed, but AQIM commanders had learned the lesson well.

\section{Objectives and ideology}

A terrorist strategy aims at political change, without necessarily controlling the population. Violence serves as 'propaganda by the deed' and aims to influence a 
target audience psychologically. Terrorists want to provoke a response, and it is this response - and not their actions - that fulfils their goals. For an insurgency, the political end goal is to establish some manner of governance of the population. An example is the MNLA which launched the uprising in Mali in January 2012 to establish the independent state of Azawad, but saw their rebellion hijacked by AQIM, MUJAO, and Ansar Dine.

The main driver of Al Qaeda's strategy is its Salafi-jihadist ideology. In a rare and extensive 2008 interview with the New York Times, Droukdel laid out AQIM's objectives, ideology, and achievements and explained the rationale behind its attacks. The first question asked was why he had joined AI Qaeda, and he replied that is was essential to join forces in the face of the 'unified oppressors' that were fermenting division among Muslim lands, stealing their riches, and corrupting their populations. As for AQIM's goals, Droukdel added:

Our general goals are the same goals of Al Qaeda the mother, and you know them. As far as our goals concerning the Islamic Maghreb, they are plenty. But most importantly is to rescue our countries from the tentacles of these criminal regimes that betrayed their religion, and their people. ${ }^{31}$

In the interview, Droukdel reiterated the Al Qaeda policy of not recognizing country borders: 'We are one nation with one religion and one language. Our history is the same but our land is divided, torn apart into states by colonialism.' In comparison to the propaganda of the Islamic State, one word was conspicuously absent during the interview: the Caliphate. For Al Qaeda, the establishment of a Caliphate is but a distant objective, one that must not be hastened. ${ }^{32}$

Essential to Al Qaeda's ideology are the teachings of the Egyptian Sayyid Qutb, notably his book Milestones (1964), and the concepts of 'far enemy' and 'near enemy'.33 Jihad is considered a personal obligation and a violent struggle against the apostate regimes in Muslim countries (the'near enemy') and against the United States and the West (the 'far enemy'). The dilemma of which to focus on has been central to AI Qaeda and AQIM in the past decade, and priorities have changed over time. In Al-Zawahiri's recent speeches, but also in Droukdel's 2008 interview, the emphasis lies on the near enemy.

Government installations and the military - the near enemy - have been repeatedly struck by AQIM, although attacks are frequently underreported by Western media. In June 2005 the remote army base Lemgheity in the Mauritanian desert was attacked by Belmokhtar's unit, killing 17 soldiers. ${ }^{34}$ Since then AQIM has conducted dozens of ambushes, killing scores of soldiers and police officers in Algeria, Tunisia, and Mali. The issue of killing civilians remains a sensitive one, eliciting debate after the multiple suicide bombings in Algiers in 2007. In the New York Times interview Droukdel reaffirmed that AQIM specifically aimed to strike at official government targets and Western interests, and that considerable effort went into avoiding Muslim casualties, but that some inevitable'collateral damage' should not detract from an attack's success. The 2015 hotel attacks in Bamako and Ouagadougou were specifically aimed at locations popular with 
foreigners, and the purported separation of Muslims from non-Muslims in the Bamako hotel was reminiscent of Belmokhtar's 2013 attack on the In Amenas gas plant, where locals were also separated from foreign employees and spared. ${ }^{35}$ The specific targeting of government and security forces, and the purported care to avoid civilian casualties, is a common feature of insurgencies and guerrilla campaigns.

AQIM has threatened the'far enemy' in countless audio and video messages. While it has attacked Western interests in the Sahel on many occasions, it has not managed to successfully launch an attack on the European mainland, unlike for instance Al Qaeda in the Arabic Peninsula (AQAP), responsible for the Charlie Hebdo attack (Paris, January 2015) or IS (Paris, November 2015). This is not for want of trying, and according to French intelligence several attacks in France have been prevented. ${ }^{36}$ The hatred against France has remained a constant factor since the GIA attacks, and Droukdel, Belmokhtar, and lyad ag Ghali have all specifically mentioned France as a primary target in their many media announcements. The 2007 killing of French tourists in Mauritania, frequent hostage takings, and specific threats have frightened away tourists and even forced the Paris-Dakar race to move to South America. AQIM, however, has not inherited the extensive GIA network that was active in London, Brussels, and Paris in the mid-nineties, nor managed to mobilize elements within the large Maghreb diaspora in France. In general, AQIM's continuous targeting of security forces and the purported attempts to avoid civilian casualties have recently been overshadowed by the hotel attacks, strongly indicating a strategy of terrorism.

\section{Organizational structure and recruitment}

The different strategies of terrorism and insurgency result in divergent organizational structures and recruitment efforts. For insurgents, whose aim is to ultimately control a population, some sort of shadow governance structure, with formal lines of hierarchy, is necessary. In parallel, the objective of building up a military force to oust the authorities requires a substantial recruitment effort among the local population. The Taliban in Afghanistan, for instance, clearly display both these elements. Groups following a terrorist strategy, conversely, do not need to mobilize the masses, but use small, secretive groups to terrorize and intimidate. They tend to exhibit selective and small-scale recruitment as a result of the secretive nature they must adopt to avoid state counterterrorist efforts.

The organizational structure of AI Qaeda has changed considerably over the years, and its secretive nature makes it hard to analyse. Under pressure from US drone strikes in Pakistan's tribal areas, Al Qaeda has evolved from a centrally directed organization into a worldwide 'franchiser' of terrorist attacks. Some consider it more a'network organization' or a'movement' than a classical organization. ${ }^{37}$ The Abbottabad letters, consisting of (only) 17 declassified letters from a treasure trove of documents captured during the Bin Laden raid in May 2011, 
offer a relatively recent insight into organizational issues. While probably not representative, the letters suggest that AQIM was not as important to AI Qaeda central as the other affiliates. AQIM appeared to have a significant degree of autonomy and generally followed advice given by the strategic leadership. ${ }^{38}$ On the other hand, letters found in Timbuktu in 2013 offer the AQIM point of view. In a letter from Droukdel to his commanders, he mentions that on several occasions he had sought advice from Al Qaeda central, but not received any guidance back. ${ }^{39}$ Aware of the risks of phone or email interception and localization long before the Snowden revelations, AI Qaeda's strategic leadership had to communicate by letter. Internal communication remains a challenge for AQIM, hampering operationalization of the chosen strategy.

AQIM has adapted and adjusted the GSPC's organizational structure, which in turn was largely based on the GIA. During the height of the Algerian insurgency, the GIA consisted of a nebulous network of armed factions headed by emirs, nominally united by the central leadership, but often autonomous in practice. ${ }^{40}$ The GIA had divided Algeria into nine zones, a practice that was continued by the GSPC. Over the past decade, more combat and terrorist operations have shifted from northern Algeria to the large southern expanses of the Sahara, Belmokhtar's fiefdom. Now operations have been divided into two sectors, a central emirate for northern Algeria and Tunisia, and a Sahara emirate for northern Mali, Niger, Mauritania, and Libya led by Djamel Okacha (Yahia Abu El Hamam). ${ }^{41}$ The central leadership consists of a 14-member Shura council, presided over by Emir Droukdel and including regional commanders and the heads of the political, military, judicial, and media committees. ${ }^{42}$ The current AQIM strategic leadership is based in the mountainous region of Kabylie to the east of Algiers, where the ethnic Berber population is engaged in an ancient struggle with the central government for more autonomy. ${ }^{43}$ AQIM's basic fighting unit is formed by a katiba (also spelled 'katibat' or 'katibah'), the Arabic word for phalanx or battalion, which was widely used during the Algerian war of independence (1954-1962). There is no standard number of fighters per katiba, and its size can vary from two dozen combatants to several hundred.

The limits of AQIM's organizational structure were laid bare during the second half of 2012, when together with Ansar Dine and MUJAO it controlled northern Mali. The expulsion of the Malian army and the conquest of the north was initiated by the Tuareg MNLA, but the alliance of convenience with the jihadist groups quickly broke down. MNLA fighters were violently evicted by the jihadist groups or switched sides. The MNLA had become unpopular through widespread pillage and instances of rape in the towns they occupied, were not supported by the non-Tuareg majority, and lacked the finances of the jihadists. ${ }^{44}$ Nonetheless, an elaborately written instruction by Droukdel to his lieutenants indicates that conflict with the MNLA was not desired. ${ }^{45}$ According to the letter, the decision to go to war with the MNLA, 'after becoming close and almost completing a deal with them.... was a major mistake.' The local commanders 
were chastised in the letter and reminded that the strategic leadership had still not received clarification on the turn of events. ${ }^{46}$

The problem of command and control - or recalcitrant commanders - led to a second strategic mistake, with disastrous consequences for their Islamic state project. Droukdel, ever mindful of the threat of a military intervention, explicitly instructed his commanders to refrain from provoking the international community, even to the point that it was 'better for you to be silent and pretend to be a domestic movement that has its own causes and concerns. There is no call for you to show that we have an expansionary, jihadi, Qaida or any other sort of project.' The order not to provoke was ignored by Ansar Dine, who launched the January 2013 attack on southern Mali, eliciting the immediate and overwhelming French military response. Belmokhtar was another difficult commander, and he was sharply criticized in an extensive 30-point letter from Droukdel for always doing things his own way. ${ }^{47}$ The criticism ranged from agreeing to an 'absurdly' low ransom for hostage Robert Fowler $(€ 700,000)$ to contacting Al-Zawahiri directly and failing to organize large attacks. This and Belmokhtar's personal rivalry with Abu Zeid, another important commander in the Sahara, undoubtedly contributed to him leaving AQIM in December 2012. Days after Operation Serval was launched, his new group called Katibat al-Mulathameen (The Masked Brigade) attacked the Algerian In Amenas gas installation, with Belmokhtar subsequently brazenly claiming he had acted on behalf of AI Qaeda.

AQIM's recruitment efforts have known significant ups and downs during the past decade. Diplomat Robert Fowler offers a candid account of life as an Al Qaeda hostage and describes the background of the fighters in Belmokhtar's katiba. ${ }^{48}$ The jihadists had varied ethic and social backgrounds, with the unit comprising fighters from all over the Sahel. The mainstay of the leadership cadre was Algerian, with 'sub-Saharan Africans clearly second class in the eyes of AQIM' ${ }^{49}$ According to analysts, this is one of the reasons that MUJAO split away, recruiting more within Songhai and other black African communities. ${ }^{50}$ Fowler also noted that many of the warriors were extremely young, some even pre-adolescent. Several years later, during the jihadists' 2012 control of northern Mali, hundreds of child soldiers were recruited..$^{51}$ As the governing authority, the jihadists could recruit and press-gang children into service without impediment. The so-called Islamic state of Azawad also attracted many foreign fighters from all over Africa, but in contrast to Syria, only a handful from Europe. The three jihadist groups grew at such a rate, setting up training camps in the north, that according to a French intelligence official, if France had waited much longer with Operational Serval it might not have had the capacity to tackle the groups on its own. ${ }^{52}$

The French intervention caused significant losses among the jihadists, killing around 700, taking 430 prisoners, and destroying some 200 tons of arms and ammunition. ${ }^{53}$ Under pressure, AQIM urged especially Tunisians not to travel to Syria but join the fight in the Maghreb: 'The front of the Islamic Maghreb today 
is in desperate need of the support of the sons of Tunisia, Morocco, Libya and Mauritania to repel the French crusade. ${ }^{154}$ This was to no avail, as the conflict in Syria is a much bigger magnet for Tunisian Salafi-jihadists than AQIM, with now probably at least 5000 Tunisians fighting there. ${ }^{55}$ This is significantly more than AQIM's current total strength. Only AQIM's small 'Uqba bin Nafi' katiba regularly attacks security forces in southern Tunisia. ${ }^{56}$ Nonetheless, three years after Serval, AQIM is again recruiting successfully in northern Mali and beyond. By providing information that can be used to target MINUSMA convoys, a local in Mali can earn around $€ 750$. In a country where the minimum wage is less than $€ 50$ a month, the temptation to work for or with AQIM can be considerable. ${ }^{57}$ AQIM's organizational structure and recruitment efforts transformed considerably during the phase that it controlled northern Mali, and reverted to the status quo ante after Operation Serval. This would not only indicate that AQIM follows a terrorist strategy, but also seems to validate this criterion to distinguish between a terrorist strategy and an insurgent one.

\section{Relationship with the population}

According to Duyvesteyn and Fumerton, groups with an insurgent strategy have a fundamentally different interaction with the local population than those with a terrorist strategy. The French pioneer in counterinsurgency doctrine, David Galula, argues that for an insurgency the'exercise of political power depends on the tacit or explicit agreement of the population or, at worst, on its submissiveness. ${ }^{58}$ Population support, either winning the 'heart and minds' or instigating a system of collective oppression, are therefore vital to an insurgency. Terrorist groups, in part due to their secretive nature, are often alienated and isolated from the broader population. By following a terrorist strategy, through violence aimed at civilians, they actually risk being considered an enemy of the people rather than of the government. ${ }^{59}$ To characterize the different levels of interaction with the local population, this section will use three levels of freedom that a group has in a certain territory. These are freedom of movement, freedom from interdiction (or safe-haven/sanctuary), and finally freedom to control the population. The last level indicates that an insurgency has achieved its objective.

Concerning freedom of movement, survival in the vast and arid plains of the Sahara is not an individual or group challenge, but a social and cultural undertaking. Many nomads and drivers habitually traverse the desert, and cordial relations with 'locals' are a required minimum to allow for an undisturbed travel or presence. The desert is literally dotted with caches of reserve petrol supplies, water reservoirs, car tyres, or other spare materials, left by transporters as a back-up in case of vehicle breakdowns or emergencies. The locals know the owner of each cache, and it is customary practice not to use anyone else's cache unless in an emergency, under the strict condition of replenishing the goods as quickly as possible. ${ }^{60} \mathrm{AQIM}$ thus has its own caches distributed throughout 
the huge Sahel area, acknowledged and left untouched by others, just as AQIM respects other caches. AQIM units equally expend a considerable effort in keeping good relations with any locals that are encountered during their travels. ${ }^{61}$ Marriage is another effective method of integrating into local communities, and Belmokhtar married into a noble Berabish tribe near Timbuktu, ensuring good relations with powerful tribes. ${ }^{62}$ Coexistence with locals was the preferred strategy of AQIM's mobile katibas, enabling them to frequently change camps to foil intelligence services that attempted to locate them. Travelling large distances, their modus operandi resemble the traditional nomadic rezzou, swift and brutal raids to destroy the enemy. AQIM's current freedom of movement stretches from Mauritania to Niger, and southern Algeria to Burkina Faso.

Sanctuaries offer reprieve from government pursuit and allow for recovery and replenishment after sustaining losses. The whole of northern Mali was effectively a safe-haven for AQIM up until 2013. Within this vast area, they developed a mountainous redoubt in the Ametetai valley, an area of about 25 square kilometres full of caves, crevices, and valleys in the Ardar des Ifoghas. AQIM chose it because it was the only location that provided natural water sources, and it frequently held its hostages there. ${ }^{63}$ The valleys were fortified by defensive positions, including heavy machinegun and mortar positions. During Operation Serval it was methodically cleared by elite French and Chadian troops, killing Abu Zeid and decimating his katiba. Now surveilled by drones and continuously at risk of a sudden air strike, it no longer offers a safe-haven. Libya has become the new sanctuary. Already during the last months of Gadhafi's reign in 2011, AQIM dispatched teams to establish jihadist cells in the southern regions. These have grown in importance since, and Libya's south-west has been termed a 'vipers nest' for terrorists by the French Defence Minister Le Drian. ${ }^{64}$

When AQIM governed parts of north Mali, from summer 2012 until Operation Serval, its relationship with the local population changed from mutual acquiescence to control. In a May 2012 audio message, Droukdel emphasized the need to gradually impose Sharia. He affirmed that it would be an error to impose all the rules of Islam in one go, but that 'places of drugs, alcohol and immorality had to be closed immediately'. He also called for his AQIM 'brothers' to ensure security in towns under their control, and that essential services such as health care, water, and electricity had to be provided. ${ }^{65}$ The Timbuktu letters, probably dating from July, reinforce his earlier message and suggest making concessions with the enemy or locals. This was vital to avoid divisions between the groups and in society, as '[t]he aim of building these bridges is to make it clear that our Mujehadin are no longer isolated in society, and to integrate with the different factions, including the big tribes and the main rebel movement and tribal chiefs.' ${ }^{\prime 66}$ This illustrates the difficulty of transitioning from a terrorist strategy to an insurgent one. The letter stresses prudence and moderation, comparing the Islamic project in Azawad to a small baby that must be nurtured and helped to stand on its own two feet (in a particularly hostile environment). 
Droukdel was adamant that the implementation of the Sharia must not be hastened. Gradual evolution had to be applied in an environment that was ignorant of religion. 'And our previous experience proved that applying Shariah this way, without taking the environment into consideration will lead to people rejecting the religion, and engender hatred toward the Mujehadin, and will consequently lead to the failure of our experiment.' ${ }^{67}$ By criminalizing alcohol, smoking, and the music and dance so central to local culture, and meting out harsh hudud punishments, the jihadists alienated large parts of the population. The deeply unpopular destruction of the shrines in Timbuktu, carried out by Ansar Dine, was equally criticized by Droukdel in his letter. In 2013 Operation Serval proved him right, and the French were welcomed as liberators by a euphoric population..$^{68}$

Since Operation Serval, AQIM has reverted to a more distant relationship with the locals. There is widespread insecurity, caused in part by the slow Algiers peace process and inter-ethnic violence, and disillusionment with the government's lack of reform. In some areas in the north, there is apparently even less electricity than during the time the jihadists were in control, provoking nostalgia among some for the occupation by AQIM. ${ }^{69}$ In November 2015, 50 masked AQIM fighters, arriving in a dozen pick-up trucks, disrupted two different intercommunal meetings in the Timbuktu region. They read out a letter encouraging reconciliation between communities, threatened those that collaborated with the 'Enemies of Islam', and promised to act against rural criminality. Before they left, the fighters distributed USB sticks containing copies of the letter, the Quran, and a video that featured the beheading of a collaborator. ${ }^{70}$

AQIM's relationship with the population has thus changed significantly over time and differs considerably in the areas where it operates. In the broader Sahel, AQIM has extensive freedom of movement and is relatively isolated from the population, although it does respect local customs in the large desert regions. This points to a strategy of terrorism, but is offset for example by current AQIM intimidation in the Timbuktu area. Here the AQIM katiba seeks to control the population, threatening collaborators and offering to provide security from petty crime. This deviates from the concept of secretive, alienated terrorist groups and illustrates the difficulty of conceptualizing AQIM's modus operandi in rigid frameworks.

\section{Criminal revenues as a goal or a means}

In the fight against terrorism, violent non-state actors are often accused of involvement in organized crime and the drug trade. This is certainly the case for AQIM, with many governments and analysts arguing that its radical Islamist rhetoric merely serves as a cover for the group's profitable criminal activities. ${ }^{71}$ Some of the policy implications of this conclusion are clear: a stronger international effort is needed to disrupt illicit trafficking in West Africa, to 'hit AQIM 
where it hurts' and deprive it of much needed funds..$^{72}$ Mindful of the lack of reliable primary sources concerning AQIM's financial income, this section will investigate AQIM's three main revenue generating activities: smuggling, the drug trade, and kidnapping for ransom.

Northern Mali has traditionally been an international crossroads for trade and commerce, and smuggling has always formed a large part of local livelihood. The northern city of Kidal is almost completely dependent on goods that come from Algeria, and the price differences of subsidized goods are readily exploited by smugglers. A matrix of networks that traditionally transports licit goods, such as petrol, tobacco, and foodstuffs, has diversified into illicit goods such as weapons, narcotics, and human-trafficking. According to Judith Scheele, the official distinction between legal and illegal trans-border trade is largely meaningless and has been replaced by what locals deem morally acceptable and what is not. ${ }^{73}$ Most of the economy is informal and thus difficult to quantify, but cigarette smuggling has always constituted a large share of the contraband. This is where Mokhtar Belmokhtar would have earned his notorious moniker' $\mathrm{Mr}$ Marlboro'. The accuracy of his reputation, however, is disputed by Mauritanian journalist Lemine Ould Salem, who has interviewed several government officials and traffickers in the region. These are all adamant that Belmokhtar was never a member of the cigarette smuggling networks. Instead he frequently frustrated their business by intercepting contraband convoys, burning cargos of cigarettes after sternly lecturing that they were 'haram. ${ }^{\prime 4}$

The drug trade has an enormous impact on the region. It took off around 2004 as European port and airport controls were tightened and South American cartels discovered the soft underbelly of West Africa. For cocaine, the most important route has become 'Highway 10', named after the 10th parallel across the Atlantic Ocean. The drugs are brought in by plane or by boat, pass through failing states like Guinea-Bissau and then transit north through Mali. ${ }^{75}$ The drugs are transported not by a single organization, but by a complex web of networks, each forming a small link in the supply chain that stretches from the Andes to Europe. ${ }^{76}$ There is little empirical evidence to support allegations of direct AQIM involvement in drug smuggling, but it is plausible to assume that it has on occasion, like many other groups in northern Mali, imposed transit fees or provided security escorts. ${ }^{77}$ Many reports credit MUJAO with a larger role in the drug trade, and the city of Gao, as their primary base and recruiting ground, is an important hub on the cocaine route. ${ }^{78}$

More important, however, is the role that the government of Mali has played in allowing the drug trade to flourish. During President Amadou Toumani Toure's rule (2001-2012), Mali's political and security structures had become deeply enmeshed in narco-trafficking, corrupting the state to the highest level. The state lost its legitimacy with the population, social relations within communities - especially between elders and the young - were disrupted, and fraught relations between ethnic groups were further exacerbated. The narco-networks 
embedded themselves so deeply in society that little changed during the jihadists' occupation of the north, and even Operation Serval has not fundamentally affected the trade. ${ }^{79}$

Kidnapping for ransom is the main source of revenue for AQIM. In early 2003, 32 European tourists were abducted by the GSPC in the Algerian Sahara. Half were freed during an Algerian military operation, while the last group ended up in northern Mali and was reportedly released for a total ransom of $€ 5$ million. $A$ precedent was set for terrorist groups to kidnap Westerners for ransom. Since 2003 , nearly all of the around 60 hostages have been released, with the notable exceptions of Edwin Dyer and Michel Germaneau, who were executed in 2009 and 2010, and Antoine De Leocour and Vincent Delory, who died during a failed rescue attempt by French special forces in 2011. The ransoms have been subject to considerable inflation with $€ 5$ million to $€ 10$ million per hostage now the reported going rate. According to an investigation by the New York Times, at least $\$ 91.5$ million had been paid to AQIM (and presumably to its partner in crime, MUJAO) between 2008 and $2014 .{ }^{80}$ This has led to a vicious cycle where each release provides the incentive for another hostage-taking.

For AQIM, hostage-taking remains a means to an end. Belmokhtar initially challenged the practice of hostage-taking and requested arbitration from AQIM's legal committee, considering it not part of jihad as the hostages were generally non-combatants and civilians. He also feared that the practice would attract unwanted attention from Western security services. AQIM's legal committee ruled that all actions aimed to defend or extend Islam were legitimate jihad actions (subject to'the Law of War in Islam'), and that Western citizens were to be regarded as combatants, as they had democratically elected governments that supported 'the War on Terror.'81 After this decision, Belmokhtar also reverted to the practice, kidnapping Robert Fowler in Niger in 2008. In the terrorism versus organized crime debate, Fowler is convinced that the former label applies to AQIM. His reasoning is worth quoting in full:

Almost since 9/11, there has been a loud debate among securocrats over whether Al Qaeda and its franchises, like AQIM, are bandits, opportunists, thugs, psychopaths, and restless, underemployed youths flying a flag of Islamic convenience, or, conversely, deeply committed religious zealots engaging, Robin Hood-like, in banditry, kidnapping and trafficking to finance the achievement of their Islamic vision. Many, probably most, have opted for some variation of the convenient first option, and many security services still favour this interpretation, mostly, I suspect, because it makes these movements easy to belittle and should make them much easier to defeat. Whatever the reasoning, based on my experience, I know it to be the wrong answer. ${ }^{82}$

The whole of Fowler's book supports the analysis that AQIM's particular fundamentalist take on Islam affected everything to do with the kidnapping and its resolution. Belmokhtar is described as a revered leader with a palpably commanding presence, principled in the radical interpretation of his faith, but who ensured that his hostages were not mistreated or tortured during their captivity. 
Fowler notes how he and his fellow hostage were continually hounded by many zealous members of the katiba 'to become slaves of Allah', but that they tenaciously managed to resist converting to Islam. Belmokhtar finally put the issue to rest by saying that a conversion could not be imposed and had to be voluntary. ${ }^{83}$

Governments invariably offer carefully formulated denials that they pay ransoms, but money is frequently paid through or by others. When confronted by the otherwise imminent death of one of their nationals, countries are less principled when it comes to the policy of offering no ransoms or significant concessions. The stance of Algeria, the United Kingdom, and the United States to under no circumstances pay ransoms is a wise one, and has been agreed as desirable state practice in the Global Counter Terrorism Forum (GCTF). It also figured in a separate declaration of the June 2013 G8 in Lough Erne. Here the agreement to 'unequivocally reject the payment of ransoms to terrorists' did not last beyond October when France paid more than $€ 20$ million to secure the release of the four hostages taken at Arlit, Niger. ${ }^{84}$ For the Sahel hostages, France, Switzerland, and Spain have paid the largest share of the ransoms, and their nationals are not coincidentally kidnapped most frequently. Nonetheless, Fowler rebukes the Anglo-Saxon allies that criticized Canada for paying the ransom that secured his release, presenting several lesser known cases of hypocrisy in Iraq and Afghanistan. ${ }^{85}$ If states and companies do manage to resist the temptation to pay large ransoms to secure the release of their nationals, this will impact enormously on AQIM's ability to finance its operations. It would also end the trend of continuing hostage takings in the Sahel.

The available evidence does not support the analysis that AQIM's jihadist rhetoric is merely the façade of a criminal organization that has self-enrichment as its primary objective. Just as Belmokhtar's reputation as a cigarette smuggler is hard to reconcile with local evidence, AQIM's role in the drugs trade seems equally marginal. This stands in stark contrast to the large role that the corrupt Malian government has played in allowing the drug trade to flourish, for instance by facilitating passage and obstructing law-enforcement efforts. This would imply that the counterterrorism strategy of cutting AQIM's drug revenue misses the point and could prove counterproductive. The drug trade probably has a bigger negative influence on Malian society than terrorism, and the international community should avoid approaching the problem through the prism of counterterrorism, where the state is both a victim and a partner in the fight. Only through fighting corruption and fundamentally reforming government institutions and practices can the problem of drugs be addressed.

\section{Conclusion}

Despite experiencing serious setbacks over the past decade, AQIM has shown remarkable continuity and resilience. The jihadist galaxy in Mali and the broader Sahel may at first glance appear to be fractured, but personal connections and 
a shared history grant AQIM considerable influence over other Salafi-jihadist groups. AQIM's current commanding cadre, the 'old guard' harking back to the Algerian GIA and GSPC, is fiercely loyal to Al Qaeda's Al-Zawahiri, and will not be seduced by IS. The reintegration of Belmokhtar into AQIM's ranks will significantly increase operational capacity, and the recent hotel attacks indicate a potential new and deadly tactic targeting civilians and Western interests.

In distinguishing between a strategy of terrorism and one of insurgency, Duyvesteyn and Fumerton's framework offers useful categories to compare the characteristics of each. First, AQIM's objectives and ideology are closely aligned with Al Qaeda, and strongly indicate a strategy of terrorism rather than insurgency. The Caliphate is not an immediate goal, and by targeting the 'far enemy' AQIM aims at provoking Western reactions. Secondly, AQIM's organization displays all the elements of a typical terrorist one: small, mobile, and clandestine units rather than a large shadow organization. When the opportunity unexpectedly arose to govern northern Mali as an 'Islamic state' in 2012, AQIM and its partners were unprepared. Despite warnings by the strategic leadership, local commanders made all the mistakes they were instructed to avoid. Thirdly, as a result of their Sahelistan project, AQIM changed its relationship with the local population from acceptance of customs and loose integration into the local fabric, to a position of governance and responsibility. Ultimately, they alienated the locals, and Operation Serval removed them from power. AQIM has since recovered and reverted to its traditional and effective modus operandi: ambushes, lightning raids, and attacks across the Sahel. In the region of Timbuktu, however, it seems that AQIM is again seeking to control the population. This is more indicative of a strategy of insurgency and illustrates the limits of trying to fit AQIM's modus operandi into a conceptual framework. After all, AQIM's different commanders display strong autonomous traits, impeding management by their strategic leadership and academic conceptualization alike.

Finally, the evidence does not support the accusation that AQIM is a criminal organization with a religious façade. Within the drug trade, AQIM plays but a small role if any at all, while government corruption and complicity are primarily responsible for the flourishing narcotics trade. AQIM's main source of income remains ransoms, and as long as these are paid new hostages will be kidnapped. As for the label insurgent or terrorist, there is no controversy in concluding that AQIM is extremely adept at using terrorist tactics, and that their intent and capacity to do so is unlikely to diminish in the near future.

\section{Notes}

1. SITE Intelligence Group, 'AQIM Announces Joining AI Muribatoon'.

2. Weiss, 'AQIM Takes Couple Hostage'.

3. Boeke and Schuurman, 'Operation "Serval'".

4. UN Security Council, Report on Situation Mali.

5. Zenn, 'Sahel's Militant "Melting Pot"'. 
6. Ibnein, 'Oumar Ould Hamahada'.

7. Lebovich, 'Hotel Attacks and Realignment'.

8. Guidère, 'Timbuktu Letters: New Insights'.

9. Filiu, Al-Qaeda in the Islamic Maghreb.

10. Marret, 'Al-Qaeda in Islamic Maghreb'.

11. Lebovich, 'Hotel Attacks and Realignment'.

12. Herbst, Talking Terrorism, 164.

13. Schmid, 'The Definition of Terrorism', 86-7 (emphasis in original).

14. See Galula, Counter-Insurgency Warfare.

15. Duyvesteyn and Fumerton, 'Insurgency and Terrorism', 27-41.

16. Schuurman, 'Defeated by Popular Demand'.

17. Khalil, 'Know Your Enemy'.

18. Kilcullen, 'Countering Global Insurgency'.

19. Tinti, Trafficking and Instability.

20. Martinez, Algerian Civil War, 209.

21. Kepel, Jihad, 263-73.

22. Amnesty International, Algeria.

23. Baralon, 'Tibhirine'.

24. Yous, Qui a tué à Benthala?

25. Mokaddem, 'Les Afghans Algériens', 75-82.

26. Guidère, Al Qaïda, Conquête du Maghreb, 63.

27. For the translated text, see Tazaghart, 'AQMI', 212-13.

28. 'Al-Qaeda "Issues France Threat"'.

29. Hunt, 'Islamist Terrorism in Northwestern Africa'.

30. Atiyah, Letter to Zarqawi.

31. 'Interview with Abdelmalek Droukdal'.

32. Pankhurst, 'Caliphate and Strategy of al-Qaeda'.

33. Gerges, The Far Enemy.

34. Salem, 'Ben Laden du Sahara', 68-72.

35. Lebovich, 'Hotel Attacks and Realignment'.

36. Jauvert, 'Mali: Histoire Secrète'.

37. Zimmerman, The Al Qaeda Network.

38. Gartenstein-Ross, 'Al Qaeda in Islamic Maghreb'.

39. Al-Qaida Papers (Letter from AQIM's Shura Council to Masked Brigade's Shura Council).

40. Baud, 'Groupe Islamique Armé (GIA)'.

41. Hagen, 'Al Qaeda in Islamic Maghreb' (presentation).

42. Al-Qaida Papers (Letter from AQIM's Shura Council to Masked Brigade's Shura Council).

43. Perrigueur, 'Les Montagnes de Kabylie'.

44. Lecocq et al.,'Hippoppotamus and Eight Blind Analysts'.

45. Siegel, 'AQIM's Playbook in Mali'.

46. Mali-al-Qaida's Sahara Playbook, Chapter 3, page 3.

47. Al-Qaida Papers (Letter from AQIM's Shura Council to Masked Brigade's Shura Council).

48. Fowler, A Season in Hell.

49. Ibid., 134, 148.

50. Lebovich, 'Mergers, MUJAO, and Mokhtar Belmokhtar'.

51. Bacchi, 'France's War in Mali'.

52. Lasserre and Oberlé, Notre Guerre Secrète, 43-44.

53. Boeke and Tisseron, 'Mali's Long Road Ahead'. 
54. Al-Andulus Media, 'Call to Youth of Islam'.

55. Schmid, Foreign (Terrorist) Fighter Estimates.

56. Zelin, Gartenstein-Ross, and Lebovich, 'Al-Qa'ida's Tunisia Strategy'.

57. Chauzal, Fix the Unfixable.

58. Galula, Counterinsurgency Warfare, 8.

59. Crenshaw, 'The Causes of Terrorism', 393.

60. See Scheele, Smugglers and Saints.

61. Fowler, A Season in Hell, 134, 148.

62. Salem, Ben Laden du Sahara, 56-9.

63. Notin, Guerre de la France, 595-8.

64. Rodier, 'Libye'.

65. Duhem, 'Nord-Mali Aqmi'.

66. Mali-al-Qaida's Sahara Playbook, Chapter 1, page 2.

67. Ibid., Chapter 1, page 3.

68. Wing, 'French Intervention in Mali'.

69. Chauzal, 'Snapshot of Mali'.

70. Presentation Chief JMAC (MINUSMA), Lille 7 December 2015.

71. Harmon, Terror and Insurgency in Sahara-Sahel, 68.

72. Detzi and Winkleman, 'Hitting Where it Hurts'.

73. Scheele, Smugglers and Saints, 122-3.

74. Salem, 'Ben Laden du Sahara', 42-5.

75. UNODC, Cocaine Trafficking in Western Africa.

76. Tinti, Trafficking and Instability.

77. Lacher, Organised Crime and Conflict.

78. Harmon, Terror and Insurgency in Sahara-Sahel, 149-51.

79. Tinti, Trafficking and Instability.

80. Callimachi,'Paying Ransoms'.

81. Guidère, 'Timbuktu Letters: New Insights'.

82. Fowler, A Season in Hell, 150-1.

83. Ibid., 227-8.

84. Follorou, 'Otages d'Arlit'.

85. Fowler, A Season in Hell, 310-11.

\section{Acknowledgements}

The author would like to thank Isabelle Duyvesteyn, Bart Schuurman, Grégory Chauzal, and Philippe Prevost for their valuable comments on an earlier draft of this article. The research assistance by Thomas Brzezinski was also much appreciated.

\section{Disclosure statement}

No potential conflict of interest was reported by the author.

\section{References}

Al-Andalus Media. 'Call to the Youth of Islam: To Those Who Aspire to Hijrah in the Way of God in the Islamic Maghreb in General and Tunisia in Particular'. Jihadology.net, 17 March 2013. http://jihadology.net/2013/03/17/al-andalus-media-presents-a-new- 
statement-from-al-qaidah-in-the-islamic-maghrib-call-to-the-youth-of-islam-aspireto-hijrah-in-the-way-of-god-in-the-islamic-maghrib-in-general-and-tunisia/.

'Al-Qaeda “Issues France Threat"'. BBC News, 14 September 2006. http://news.bbc.co.uk/2/ hi/europe/5345202.stm.

Al-Qaida Papers. Associated Press. Accessed 10 February 2016. http://hosted.ap.org/ specials/interactives/_international/_pdfs/al-qaida-belmoktar-letter-english.pdf.

Amnesty International. Algeria: Repression and Violence Must End. October 1994. Index no. MDE 28/008/1994. https://www.amnesty.org/en/documents/MDE28/008/1994/en/.

Bacchi, Umberto. 'France's War in Mali: Child Soldiers on the Frontline'. International Business Times, 16 January 2013. http://www.ibtimes.co.uk/mali-child-soldiersislamists-france-424816.

Baralon, Marguax le. 'Tibhirine, les Expertises Fragilisent la Version Officielle'. LaCroix, 2 July 2015. http://www.la-croix.com/Actualite/France/Tibhirine-les-expertisesfragilisent-la-version-officielle-2015-07-02-1330468.

Baud, Jacques. 'Groupe Islamique Armé (GIA)'. Global Terror Watch, 7 June 2012. http:// www.globalterrorwatch.ch/?p=699.

Boeke, Sergei, and Bart Schuurman. 'Operation "Serval": A Strategic Analysis of the French Intervention in Mali, 2013-2014.' The Journal of Strategic Studies 38, no. 6 (2015): 1-25. doi:10.1080/01402390.2015.1045494.

Boeke, Sergei, and Antonin Tisseron. 'Mali's Long Road Ahead.' The RUSI Journal 159, no. 5 (2014): 32-40. doi:10.1080/03071847.2014.969942.

Callimachi, Rukmini.'Paying Ransoms, Europe Bankrolls Qaeda Terror'. The New York Times, 29 July 2014. http://www.nytimes.com/2014/07/30/world/africa/ransoming-citizenseurope-becomes-al-qaedas-patron.html?_r=0.

Chauzal, Grégory. Fix the Unfixable. Dealing with Full-Blown Crisis and Instability: How to Bring Greater Stability to the Sahel? CRU Policy Brief. The Hague: Clingendael, 2015.

Chauzal, Grégory. 'A Snapshot of Mali Three Years after the 2012 Crisis'. Clingendael, 8 June 2015. http://www.clingendael.nl/publication/commentary-snapshot-mali-threeyears-after-2012-crisis.

Crenshaw, Martha.'The Causes of Terrorism'. Comparative Politics 13, no. 4 (1981): 379-399. http://links.jstor.org/sici?sici=0010-4159\%28198107\%2913\%3A4\%3C379\%3ATCOT\% 3E2.0.CO\%3B2-8.

Detzi, Daniel, and Steven Winkleman. 'Hitting Them Where it Hurts: A Joint Interagency Network to Disrupt Terrorist Financing in West Africa.'Studies in Conflict \& Terrorism 39, no. 3 (2016): 227-239. doi:10.1080/1057610X.2015.1099994.

Duhem, Vincent. 'Nord-Mali - Aqmi: Abdelmalek Droukdel Appellee à Imposer 'Graduellement' la Charia'. Jeune Afrique, 24 May 2012. http://www.jeuneafrique. com/175961/politique/nord-mali-aqmi-abdelmalek-droukdel-appelle-imposergraduellement-la-charia/.

Duyvesteyn, Isabelle, and Mario Fumerton. 'Insurgency and Terrorism: Is there a difference?' In The Character of War in the 21st Century, edited by Caroline HolmqvistJonsater and Christopher Coker, 27-41. London: Routledge, 2009.

Filiu, Jean-Pierre. Al-Qaeda in the Islamic Maghreb: Algerian Challenge or Global Threat? Washington, DC: Carnegie Endowment for International Peace, 2009. http:// carnegieendowment.org/files/al-qaeda_islamic_maghreb.pdf.

Follorou, Jacques. 'Otages d'Arlit: Les Dessous de la Négociation'. Le Monde, 30 October 2013. http://www.lemonde.fr/afrique/article/2013/10/30/otages-d-arlit-les-dessousd-une-libera_3505240_3212.html.

Fowler, Robert R. A Season in Hell: My 130 Days in the Sahara with Al Qaeda. Toronto: Harper Collins, 2011. 
Galula, David. Counter-Insurgency Warfare: Theory and Practice. New York: Frederick A. Praeger, 1964. http://louisville.edu/armyrotc/files/Galula\%20David\%20-\%20 Counterinsurgency\%20Warfare.pdf.

Gartenstein-Ross, Daveed. 'Al Qaeda in the Islamic Maghreb and Al Qaeda's Senior Leadership'. Defend Democracy, 19 January 2013. http://www.defenddemocracy.org/ media-hit/al-qaeda-in-the-islamic-maghreb-and-al-qaedas-senior-leadership/.

Gerges, Fawaz. The Far Enemy: Why Jihad Went Global. Cambridge: Cambridge University Press, 2005.

Guidère, Mathieu. Al-Qaïda à la Conquête du Maghreb: Le Terrorisme aux Portes de l'Europe. Monaco: Éditions du Rocher, 2007.

Guidère, Mathieu. 'The Timbuktu Letters: New Insights about AQIM'. Res Militaris 4, no. 1 (2014). http://resmilitaris.net/ressources/10184/89/res_militaris_article_guid_re_ new_insights_about_aqim.pdf.

Hagen, Andreas. 'Al Qaeda in the Islamic Magreb'. Presentation in AEl's Critical Threats Project, March 2014. http://www.criticalthreats.org/al-qaeda/hagen-aqim-leadersand-networks-march-27-2014.

Harmon, Stephen A. Terror and Insurgency in the Sahara-Sahel Region: Corruption, Contraband, Jihad and the Mali War of 2012-2013. Farnham: Ashgate, 2014.

Herbst, Philip. Talking Terrorism: A Dictionary of the Loaded Language of Political Violence. Westport, CN: Greenwood, 2003.

Hunt, Emily. 'Islamist Terrorism in Northwestern Africa: A "Thorn in the Neck" of the United States?' Policy Focus, no. 65, February 2007. http://www.washingtoninstitute. org/uploads/Documents/pubs/PolicyFocus65.pdf.

Ibnein, Abu. 'Oumar Ould Hamahada: A Case Study of the Bridges Between Three Groups'. Geneva Centre for Training and Analysis of Terrorism, Centre's Note (CN) 3, 10 January 2013.

'An Interview with Abdelmalek Droukdal'. The New York Times, 1 July 2008. http://www. nytimes.com/2008/07/01/world/africa/01transcript-droukdal.html?_r=0.

Jauvert, Vincent. 'Mali: Histoire Secrète d'Une Guerre Surprise'. Le Nouvel Observateur, 10 February 2013. http://globe.blogs.nouvelobs.com/archive/2013/02/08/mali-histoiresecrete-d-une-guerre-surprise.html.

Kepel, Gilles. Jihad: The Trail of Political Islam. Translated by Anthony F. Roberts. London: I.B. Tauris, 2002.

Khalil, James. 'Know Your Enemy: On the Futility of Distinguishing Between Terrorists and Insurgents.' Studies in Conflict \& Terrorism 36, no. 5 (2013): 419-430. doi:10.1080/ 1057610 X.2013.775501.

Kilcullen, David J. 'Countering Global Insurgency'. Journal of Strategic Studies 28, no.4 (2005): 597-617. doi:10.1080/01402390500300956.

Lacher, Wolfram. Organized Crime and Conflict in the Sahel-Sahara Region. Washington, DC: Carnegie Endowment for International Peace, 2012. http://carnegieendowment. org/files/sahel_sahara.pdf.

Lasserre, Isabelle, and Thierry Oberlé. Notre Guerre Secrète au Mali: Les Nouvelles Menaces Contre la France. Paris: Fayard, 2013.

Lebovich, Andrew. 'The Hotel Attacks and Militant Realignment in the Sahara-Sahel Region'. CTC Sentinel 9, no. 1 (2016): 22-28. https://www.ctc.usma.edu/posts/thehotel-attacks-and-militant-realignment-in-the-sahara-sahel-region.

Lebovich, Andrew. 'Of Mergers, MUJAO, and Mokhtar Belmokhtar'. Al-Wasat, 23 August 2013. https://thewasat.wordpress.com/2013/08/23/of-mergers-mujao-and-mokhtarbelmokhtar/.

Lecocq, B., G. Mann, B. Whitehouse, D. Badi, L. Pelckmans, N. Belalimat, B. Hall, and W. Lacher. 'One Hippopotamus and Eight Blind Analysts: A Multivocal Analysis of the 2012 
Political Crisis in the Divided Republic of Mali.' Review of African Political Economy 40, no. 137 (2013): 343-357. doi:10.1080/03056244.2013.799063.

Mali-al-Qaida's Sahara Playbook. Associated Press. Accessed 10 February 2016. http:// hosted.ap.org/specials/interactives/_international/_pdfs/al-qaida-manifesto.pdf.

Marret, Jean-Luc. 'Al-Qaeda in Islamic Maghreb: A "Glocal” Organization.' Studies in Conflict \& Terrorism 31, no. 6 (2008): 541-552. doi:10.1080/10576100802111824.

Martinez, Luis. The Algerian Civil War, 1990-98. New York, NY: Columbia University Press, 2000.

Mokaddem, Mohamed. Les Afghans d'Algérie, de la Djamaâ à El Qaïda. Algeria: ANEP, 2002.

Notin, Jean-Christophe. La Guerre de la France au Mali. Paris: Tallandier, 2014.

Pankhurst, Reza. 'The Caliphate, and the Changing Strategy of the Public Statements of al-Qaeda's Leaders.' Political Theology 11, no. 4 (2010): 530-552. doi:10.1558/poth. v11i4.530.

Perrigueur, Elisa. 'Les montagnes de Kabylie, refuge de nombreux djihadistes'. Le Monde, 24 September 2014. http://www.lemonde.fr/international/article/2014/09/24/lesmontagnes-de-kabylie-refuge-de-nombreux-djihadistes_4492713_3210.html.

Rodier, Alain. 'Libye: Le Nid de Vipères'. Centre Français de Recherche sur le Renseignement, Note d'Actualité no. 352 (2014). http://www.cf2r.org/fr/notes-actualite/libye-le-nidde-viperes.php.

Salem, Lemine Ould M. Le Ben Laden du Sahara: Sur les Traces du Jihadiste Mokhtar Belmokhtar. Paris: La Martinière, 2014.

Scheele, Judith. Smugglers and Saints of the Sahara: Regional Connectivity in the Twientieth Century. New York, NY: Cambridge University Press, 2015.

Schmid, Alex P.'The Definition of Terrorism'. In Handbook of Terrorism Research, edited by Alex P. Schmid, 39-98. London: Routledge, 2011.

Schmid, Alex P. Foreign (Terrorist) Fighter Estimates: Conceptual and Data Issues'. ICCT Policy Brief. The Hague: ICCT, October 2015. http://icct.nl/wp-content/uploads/2015/10/ ICCT-Schmid-Foreign-Terrorist-Fighter-Estimates-Conceptual-and-Data-IssuesOctober20152.pdf.

Schuurman, Bart.'Defeated by Popular Demand: Public Support and Counterterrorism in Three Western Democracies, 1963-1998.' Studies in Conflict \& Terrorism 36, no. 2 (2013): 152-175. doi:10.1080/1057610X.2013.747072.

Siegel, Pascale Combelles. 'AQIM's Playbook in Mali'. Combating Terrorism Center at West Point, 27 March 2013. https://www.ctc.usma.edu/posts/aqims-playbook-in-mali.

SITE Intelligence Group. 'AQIM leader Announces joining of AI Muribatoon, Radisson Blu as First Joint Act'. SITE Intelligence Group, 4 December 2015. https://news.siteintelgroup. com/Jihadist-News/aqim-leader-announces-joining-of-al-murabitoon-radisson-bluattack-in-bamako-as-first-joint-act.html.

Tazaghart, Atmane. AQMI: Enquête sur les Héritiers de Ben Laden au Maghreb et en Europe. Paris: Jean Picollec, 2011.

Tinti, Peter. Illicit Trafficking and Instability in Mali: Past, Present and Future (Research Paper). Geneva: Global Initiative against Transnational Organized Crime, 2014.

United Nations Office on Drugs and Crime. Cocaine Trafficking in Western Africa. UNODC. https://www.unodc.org/documents/data-and-analysis/Cocaine-trafficking-Africa-en. pdf.

UN Security Council. Report of the Secretary-General on the Situation in Mali, S/2015/1030. 24 December 2015. http://www.securitycouncilreport.org/atf/cf/\%7B65BFCF9B6D27-4E9C-8CD3-CF6E4FF96FF9\%7D/s_2015_1030.pdf.

Weiss, Caleb. 'AQIM Takes Australian Couple Hostage in Northern Burkina Faso'. The Long War Journal, 16 January 2016. http://www.longwarjournal.org/archives/2016/01/aqimtakes-australian-couple-hostage-in-northern-burkina-faso.php. 
Wing, Susanna D. 'French Intervention in Mali: Strategic Alliances, Long-Term Regional Presence?' Small Wars \& Insurgencies 27, no. 1 (2016): 59-80.

Yous, Nesroulah. Qui a tué à Bentalha?. Paris: La Découverte, 2000.

Zelin, Aaron Y., Daveed Gartenstein-Ross, and Andrew Lebovich. 'Al-Qa'ida in the Islamic Maghreb's Tunisia Strategy'. CTC Sentinel 6, no. 7 (2013): 21-25. https://www.ctc.usma. edu/posts/al-qaida-in-the-islamic-maghrebs-tunisia-strategy.

Zenn, Jacob. 'The Sahel's Militant 'Melting Pot': Hamadou Kouffa's Macina Liberation Front (FLM)'.TerrorismMonitor13, no.22 (2015):3-6.http://www.jamestown.org/programs/tm/ single/?tx_ttnews[tt_news] $=44593 \&$ cHash $=8 b 46 b 953 b 2373675 d 248929 a 39 f 8264 b \#$. VrsOAObwDuT.

Zimmerman, Katherine. The Al Qaeda Network: A New Framework for Defining the Enemy. AEl's Critical Threats Project, 2013. http://www.aei.org/wp-content/uploads/2013/09/the-al-qaeda-network-a-new-framework-for-defining-the-enemy_133443407958.pdf. 